Available online at: http://journal.uinsgd.ac.id/index.php/IJIK

IJIK Vol. 9. No. 2: 41 - 47

\title{
WOMEN'S ACTIVITIES IN THE LIFE OF MUHAMMAD (570-632 AD)
}

\author{
Shidqy Munjin \\ Pascasarjana UIN Sunan Gunung Djati Bandung \\ Email : Shidqymunjin@gmail.com
}

\begin{abstract}
The main problem in this study is to uncover three problems related to women in the time of Muhammad. First, regarding the position of women during the time of Muhammad. Second, concerning the extent of women's involvement in various activities during the time of Muhammad, both in the period before and after it. Third, what problems were faced by women at that time and how they affected their activities. This research is based on the library research of the earliest classic books in the UIN SGD Bandung Library and the al-Musaddadiyyah Garut Foundation Library, such as Ibn Ishaq, Ibn Hisham, al-Waqidi, Ibn Sa'd, and al- Tabari. The results of this study indicate that Muhammad was a person who cared deeply about human rights especially those relating to women. This conclusion is proven by his attitude which always defends the oppressed. He always displayed this defence attitude before being appointed as a prophet, and even more firmly when he was appointed as a prophet. The different characteristics of Muhammad's attitude towards women before and after the prophecy were influenced by economic factors, security, and the social system that prevailed in each of these periods.
\end{abstract}

Keywords: Woman, Activity, Age

\section{INTRODUCTION}

Many women who feel uneasy because it seems as if there is a darkening of history to their world. As a confession, Mernissi felt that Muslim women today do not care about their future conditions (Mernissi, 1997). They only know and realize that they will grow old. Yet to knit the future, it needs historical documentation that can be stored and given in relay to subsequent generations.

Writing women's history, especially in Indonesia, is a study that is quite behind. Rarely are their serious studies at the level of dissertations that discuss women's history. In contrast to the writing of history in the West, where women's history has become a speciality in addition to other histories. This is proven by the formation of the American Historical Association (AHA) which successfully published Teaching Women's History, a guidebook for teaching women's history at the first level of the university.

In its development, historical writing often positions women as a contributor as reflected in several studies that use the word "role". The word describes that women never stand alone.

One of the reasons that historians have always used as reasons why historians lack attention to the emancipation of women is because historians are too focused on political and military history, two worlds that women rarely enter. Studies like this are unfair studies because they will position women as second sex (Hasan, 2019). Likewise with the writing of several biographies of women warriors who have not been able to eliminate the impression that women as a creature who only take care of their world, an exclusive world.

Different cases occur in Islam. Substantially, Islam does not recognize discrimination between men and women. Islam places women as equal partners for men. Even if there are differences, then it is due to the main functions and tasks that religion imposes on each sex, so that the differences do not result in one

* Copyright (c) 2019 Shidqy Munjin

This work is licensed under a Creative Commons Attribution-ShareAlike 4.0 International License.

Received: 10 May 2019; Revised: 3 Juny 2019; Accepted: 10 Juny 2019 
feeling superior to the other. Both complement and help each other in playing out their functions in life and life. Islam proclaims the equality of men and women as well as the integration between the two in playing their respective functions. This can be seen in the expression of the Koran which directly aligns the position of men and women, including those contained in QS al-Nisa ': 1, 6, 31, 74, and 97.

Islamic teachings in some places also give special privileges to women. This is illustrated in the Koran which names several sûrahs with the names of women. The attitude of the Koran like this illustrates a high recognition of the services of women. A form of documentation of all activities carried out by women.

In its history, Islam has always involved the role of women in several important missions. Even the first to believe in the Prophet was Khadija, a rich widow who became the wife of the Prophet himself. And in its course, history recorded how big the role played by Khadijah in developing Islamic da'wah. After Islam developed, a woman named Sukainah Bint Husain (d. 735 AD) emerged. He is the grandson of the Prophet Muhammad who had a high level of education, famous for his extensive knowledge, his expertise in reading and writing, and his beauty.

Writing the history of women like this is the teaching of the Koran that must be developed. The Koran exemplifies this by mentioning in detail the stories of women in it. Writing women's history is a shortcut that should be taken by those who feel that there is injustice towards women. With the writing of women's history, you will see a picture of the actual position of women.

The spirit of the Koran who appreciates the services of these women is very inspiring Muslim historians. Muslim historians always give a special portion for the documentation of women's emancipation. Like the oldest biography called Thabaqât, both Ibn Sa'd and Ibn Khayyath. In Thabaqât alKubrâ Ibn Sa'd included 5,554 biographies from different levels, from best friends to tâbi 'al-atb'. Of all the biographies he included there were 629 women from among friends and tâbi'în (Nurkholidah, 2016). In the book, Usad al-Ghaba fî Ma'rifat al-Shahâbah Ibn al-Athir included 7,711 friends, of whom 1,023 were women (Abd al-Barr \& bin Abd al-Allah, 1992). In the book, al-Istîâb fî Ma'rifat al-Ashhâb Ibn 'Abdil Bar includes 3,224 male friends and 1,002 female friends (Abd al-Barr \& bin Abd al-Allah, 1992). In Siyar A'lam al-Nubal 'by al-Dzahabi, an encyclopaedia of bright people in each age contains 5,964 lists of people, 121 of whom are women. In this book, al-Dzahabi does not separate the list of men and women but arranges it according to the year of his death (Abdurrahman, 2012). Ibn Hajar al-qAsqalani in the book al-Ishâbah fî Tamyîz al-Shahâbah included 12,308 lists of friends with 1,550 of whom were women (bin Sidik \& Berahim, 2013). A fairly old document entitled Ma'rifat al-Shahâbah by Ibn Mandah also included 21 female biographies from the 590 biographies listed in it (Suhra, 2013). And there are many other biographical books, both written in the classical period or the Middle Ages that are very concerned about the position of women. All of this data is strong evidence that Islam is a religion that positions women equal to men while dismissing allegations that Islam is a religion that is very discriminatory towards women (Suhra, 2013).

Because all the data recorded in the books above is only limited to biography, the exclusive impression is inevitable. It is as if the person who is being explained by his biography is separate from the social order around him. So for that, we need a study that summarizes the data and their reconstructions in the form of historical narratives so that it will show the form of an active role of women in their historical space. This historical approach to the problem of the complicated position of women will certainly be more easily accepted by many parties compared to studies using doctrinaire approaches that are often considered dogmatic. 
To prove the concern of Muhammad and Islam for women, a thorough study of women's emancipation during Muhammad's life before becoming a prophet is needed, then the emancipation of women during Muhammad's poet-prophet status, both in Mecca and Medina. By comparing the history of women in these three different periods, it will be seen the extent of the role of Islam in lifting the rank of a woman. Likewise, with the research, it will be seen clearly, whether the Islamic attitude towards women is a standard doctrine or a form formed due to non-standard conditions and can be developed further. Also, the study of women who lived during Muhammad's time was to look at the other side of Islamic teachings. If all this time the study of Islamic teachings is seen from the side of the Prophet, which is often used as a one-man show (single figure) in the development of Islamic teachings, then the study of society during the Prophet's time is a space that must be filled. As explained by the Muslim hermeneut that the khithâb (goal) of the Islamic da'wah is not the Prophet alone, but also more important is the community around him. So that studies like this will make Islamic teachings look more grounded.

\section{METHODOLOGY}

As a historical study, in principle, the techniques and steps taken in this study are: HeuristicsCriticism strengthened by primary and secondary sources. And made into descriptive narrative form (Sugiyono, 2013).

\section{RESULT AND DISCUSSION}

\section{Medina Women's Period Activity}

All followers of the Prophet faced pressure and torture in Mecca, then they emigrated to defend and save their beliefs. When the Prophet arrived in Medina, all policies among the Muslims could already be controlled by the Prophet himself. This opportunity was used by the Prophet to form a new, more advanced and civilized structure of the Medina community. Then in this Medina period, various advances can be seen in several fields; like economics, government politics, education, and so on. This progress has made it possible for all people to work in these fields, including, in this case, women.

\section{Social Activity}

Women's activity in the social field in Medina is concrete evidence of the emancipation carried out by the Prophet. In this period women have shown their agility to compete (istibâq) with men.

Madinah women who used to decorate, work, and interact with men in a balanced way, began to be transmitted to women in Mecca who emigrated. Abdul Walid ibn Aiman received testimony from his father that 'Aisha was angry at her maid who did not want to dress in clothes for five dirhams. Even though Madinah women like to dress in such clothes (Awalia, Triyono, \& Nur Latifah, 2016).

In another statement also mentioned that there is a friend of a wealthy woman from the Ansar. The woman named Ummu Syuraik. He has a habit of spending a lot of his wealth for the benefit of Allah's religion. Besides that, he also often opens his house to be visited by guests and he treats the guests (alNisâbûrî, 2017). Umm al-'Ala also claimed that when Uthman ibn Mazh'un was ill he cared for him in his own home until Uthman died (al-Nisâbûrî, 2017).

Some of the information above shows how harmonious social interaction between men and women at the time of the Prophet in Medina. Even though in this Medina period the verse on hijâb (the barrier between men and women when communicating) came down, they still not only exhibited competitive 
interactions but were also cooperative. The social interaction carried out actively by women in Madinah turned out to have a significant impact on the systems and patterns of marriage and also their education.

\section{Religious Activities}

Religious conditions in Medina are far better than conditions in Mecca. This is very reasonable because the conditions in Mecca of the Prophet and all his followers carry out all his religious rituals in a condition of fear and distress. But upon arrival in Medina, where the pressure and fear had disappeared, all religious rituals were carried out openly. This condition also affects the religious conditions of women. When in Mecca, women are not allowed to go to places of worship for men because they are worried that there will be an attack from the Makkah community. But in Madina, precisely women are no less active with men in their activities in the mosque and even all religious fields that are usually done by men. Fatima bint Qais when she heard the call to prayer she would immediately go to the mosque and always be in the forefront of women, that is, right after the last row of men (al-Nisâbûrî, 2017). The Prophet not only gave full religious rights to women, but he also protected and protected their rights. When the women of the Prophet's followers who emigrated to Medina had arrived, and Umm Kaltsum bint Uqbah ibn Abu Mu'ith was among those who joined the Prophet. At that time Umm Kaltsum was still young. Then his family came to ask the Prophet for him to return Umm Kaltsum to them. However, their request was rejected by the Prophet (al-Nisâbûrî, 2017). This was done by the Prophet for fear that Umm Kulthum brought back by his family would deprive his religious rights. In the sixth year of the hijrah, the Prophet performed his first Umrah. The implementation of the Umrah began with the recognition of the Prophet who dreamed of entering the Masjid al-Haram in Makkah with all his followers. They all do tawaf and umrah. After hearing the Prophet's confession, the friends immediately got ready to leave for Makkah. The Prophet's departure for Makkah was heard by the inhabitants of Makkah. So they deliberated to draw up a plan to frustrate the Prophet's Umrah. So Suhail ibn 'Amr was sent as a delegation to Mecca to meet the Prophet. The meeting resulted in an agreement called the Hudaibiyyah Agreement (Shulh al-Hudaibiyyah). The agreement contained a ceasefire (arbitration) between residents of Mecca and Medina for one year. Also, the Prophet and his followers had to frustrate his umrah in that year and were only allowed to perform the Umrah the following year. Then the Umrah in the sixth year is called Umrah al-hudaibiyyah. The above agreement cannot be accepted by many friends who are already longing to enter Makkah. Instead of the failed Umrah worship, the Prophet told his followers to cut their hair and sacrifice in Hudaibiyyah. Feeling disappointed with the agreement, many followers of the Prophet did not directly carry out the Prophet's instructions. The Prophet even had to repeat the instructions three times. But because his followers still did not carry out his instructions, the Prophet went straight to Umm Salamah to ask for a solution. Finally, Umm Salamah provided a valuable opinion input to the Prophet, so that the Prophet immediately shaved his hair and sacrificed in front of his followers without speaking a word. And after seeing the Prophet's actions, finally, all his followers carried out their instructions (Ashur \& 'Ashur, 2018). Expertise and dexterity in acting were also shown by Umm Salamah in the conversion of some of the family of the Apostles who were known as those who opposed the propaganda of Islam. The incident occurred at the time of Fath Makkah (control of the city of Mecca by the Muslims), the Prophet came with his soldiers with greatness and numbers that had never been witnessed by the Arabs, as a result, the polytheists were afraid, so they went out of the house to meet the Prophet to repent and declare their Islam. These included Abu Sufyan ibn alHarts ibn 'Abdul Muttalib (son of the Prophet's uncle) and Abdullah ibn Abi Umayyah ibn al-Mughirah (the 
Prophet's aunt's son from the father and brother of Umm Salamah). When they both asked permission to enter the Prophet, the Prophet was reluctant to permit fear of what would be done to the Prophet and his followers, as was done before the Fath of Mecca. It seems that Umm Salamah understands the Prophet's concern, So with Umm Salamah acting as an intermediary and with a familial approach. Umm Salamah said to the Prophet, "O Prophet, they are both your uncle's son and your aunt's son and sister-in-law." The Prophet replied, "There is no need for me with both of them. As for my uncle's son, I have been treated by him unkindly. As for my aunt's son (from my father) as well as my brother-in-law, he said in Mecca what he said

Ummu Salamah understood that Abu Sufyan and Abdullah ibn Umayyad wanted to embrace Islam, so they again begged the Prophet with compassion. Finally, the Prophet's heart melted, then allowed both of them to enter. Then enter both and declare Islam and repent before the Prophet (Atmawati, 2016).Umm Salamah is smart and takes a stand and acts in every situation and case. Umm Salamah has taught us that solving a case requires the right strategies and approaches.

Besides that, another attitude shown by Umm Salamah, which is no less important in completing every matter is a sincere intention and only hopes for God's blessing. The greatness and courage of Umm Salamah were also shown in several wars such as the Khaibar War, the siege of Ta'if, the Hawazin war and the Thaqif war. In these wars, Umm Salamah along with other Muslim women provided water and logistics for Islamic soldiers and also served as a red cross to treat wounded soldiers (Atmawati, 2016).

The verses of al-Quran surah al-Mujadilah also fell due to complaints of a woman named Khaulah or Khuwailiyah bint Tsa'labah about her husband named Aus ibn Shamit who had sent her. This shows that the religious position of women in Islam is the same as that of men, and even revelations were directly revealed to solve the problems they raised.

\section{Economic Activity}

Economic conditions will correspond to social conditions. The majority of people living in the Hijaz region, especially Makkah and Madinah, work as traders or gardeners. They are also people who are used to doing crafts. Be it sewing crafts, spinning, and so forth.

Through several systems as outlined in the shari'ah legal channels, such as inheritance law, zakat obligation, recommendations for setting aside a portion of the property for waqaf, sodakah, grants, etc., so that the abilities and welfare obtained by some people can also be enjoyed by others whose fate is less fortunate. Therefore, since the spirit of waqaf was spearheaded by prominent friends such as: 'Umar ibn Khathab (who forgave the best and most valuable land in Khaibar), Abu Talha (who gave up his date garden in front of the Medina mosque known as Biruha' ). Usman ibn Affan (who condoned the springs needed by the community, known as 'Ainu Rumah), bought the well from someone from Bani Ghifar for 35,000 (thirty-five thousand) dirhams.

Furthermore, Muslim women ranging from the wives of the Prophet, such as Umm Salamah, Hafshah bint Umar, Shofiyah bint Huyaiy, 'Aisyah, Umm Habibah, Zainab bint Jahsyi, to female friends such as Asma bint Abu Bakr, Fatima bint Huyaiy,' Aisha, Umm Habibah, Zainab bint Jahsyi, to female friends such as Asma bint Abu Bakar, Fatima bint Muhammad, and Umma Sulaim, Umm Sulaim, has been involved in the waqf movement, so Jabir's companions said, "There is no companion of the Prophet who has wealth unless he forgives part of his wealth".

Yusuf al-Qardhawi, through his notes published in the Auqâfunâ Journal, July 2008, illustrates the spirit of sharing among early women, as follows: 
Umm Dzarah, Aisyah's assistant told her, that Abdullah ibn Zubair, nephew 'Aisha sent money to her biib, two bags of 180 thousand dirhams (each bag contained 90,000 dirhams). Then is Aisha asked for a laver. He was fasting at that time. Instantly he ordered his servants to distribute the money to other people who were deemed as needy. In the afternoon he called Umm Dzaroh and told him to prepare food to break the fast. So the servant provided a piece of bread and oil. However 'Aisha asked her to buy meat. But the maid reported that he had distributed all the money.

Malik ibn Anas in his Muwaththa narrated that one day 'Aisha was visited by a poor person who asked for food, even though on that day she was fasting and at home she had no preparation except for a piece of bread. But he ordered his servants to give the bread to the poor. The assistant tells him that there is the only food available for him to break the fast. But is Aisha still ordered to give the bread to the poor man. Then the bread is immediately given. In the afternoon, it turned out there was someone who sent food in the form of our food with dessert. Then is Aisha called out to her maid, smiling stating that the food she received was better than the bread she had given earlier.

Nafi 'narrated that Hafshah (wife of the Prophet) sold her jewellery worth 20,000 dirhams, and endowed it for the women of the al-Khatthab family, as well as for some types of jewellery to wear when there was a need (such as a wedding party) or rent. Asma 'bint Abi Bakar donated her house, may not be inherited, sold, or donated to anyone. Umm Habibah (wife of the Prophet) donated a large plot of land to his servants and their offspring, on the condition that it should not be sold, granted or bequeathed.

'Atha' said that Mu'awiyah once sent a gift to 'Aisha in the form of a gold jewellery box in which there was a jewel whose price was estimated to be 100,000 thousand dirhams, but the jewels were later distributed by' Aisha distributed to the Prophet's wives, he only took one of these pieces of jewelry (alQardhawi, 1993). That all can give an idea of how the "spirit of sharing" has become a character among high-level women, since the early days of the development of Islam.

Jabir ibn Abdullah stated that when his aunt was divorced by her husband, and his biologist intended to harvest the dates on his iddah, there was a man who rebuked him so as not to go out and his house. Then the biologist went to the Prophet to ask about the problem. The Prophet precisely supported his biib's actions so he could eat and give alms (Bayan, 2010).

Sa'ad ibn Mu'adz said that a slave girl belonging to Ka'ab ibn Malik one day tended the goat in the Sal 'area (a hilly region in Medina). Suddenly there is a goat that wants to die. Then the female slave took the broken stone, then slaughtered the stone with it. When it was asked to the Prophet, he suggested eating it (Bayan, 2010).

Maimunah, one of the Prophet's wives, freed slave girls without the Prophet's knowledge. Kuraib, Ibn Abbas's slave said that Maimunah bint al-Harith told her that he freed a slave girl without asking the Prophet for permission first. On the day the Prophet's turn was in his house, he confessed to the Prophet about what he had done. When the Prophet found out, the Prophet did not say anything and only advised to give it to his family relatives (Bayan, 2010).

When the marriage ceremony of the Prophet Muhammad, Umm Sulaim bint Milhan gave a gift to the Prophet Muhammad on his behalf, not on behalf of her husband. Umm Sulaim told his son, Anas ibn Malik to give food to the Prophet as a wedding gift. Umm Sulaim also told Anas to immediately give the food to the Prophet while leaving his regards to him (al-Qardhawi, 1993).

Asma bint Abu Bakar claimed to have offered money from the sale of female slaves without the knowledge of her husband, Zubair ibn Awwam. When Zubair came to see him and asked for the results of his sale, then Asma claimed to have given all the proceeds from the sale of his slaves (Bayan, 2010). 
The events above show that in Islam, women have independence in possessing property. Even ownership rights are not only in assets but also in other matters. When in pre-Islamic times women had no property rights at all, even they were only possessions, but in Islam, especially in this Medina period, women were able to accept their rights so that they could fulfil their obligations.

\section{CONCLUSION}

Before Muhammad was appointed a prophet, the position of women amid Arab society, in general, was very low and apprehensive. At this time women have no political rights at all. At a time like this, Muhammad grew up as a young man who greatly valued the human status of all people, including the status of humanity and the rights of women. So his attitude that is very concerned about the status and rights of women is an innate character that he had before he was appointed as a prophet. When Muhammad was appointed as a prophet, his followers underwent various oppressions that made women very vulnerable if they were too active in outside areas. This situation makes women's activities less developed. As for Madinah, where conditions have stabilized, security has begun to be guaranteed, women have full and equal social rights with men. In the fields of education, marriage and inheritance they have the same rights as men. The different characteristics of Muhammad's attitude towards women before and after the prophecy were influenced by economic, political, security, and social system factors that prevailed in each of these periods. But the difference in attitude remains in its main principle, namely equality of rights and obligations between men and women.

\section{REFERENCES}

Abd Al-Barr, I., \& Bin Abd Al-Allah, Y. (1992). Al-Isti'ab Fi Ma'rifat Al-Ashhab. Investigation: Ali AlBajawi), Dar Al-Jil, Beirut.

Abdurrahman, M. (2012). Imam Al-Bukhari Dan Lafal Al-Qur'an. Kalimah: Jurnal Studi Agama Dan Pemikiran Islam, 11(1), 120-131.

Al-Nisâbûrî, A. Al-H. M. (2017). Bin Al-Hajjâj Bin Muslim Al-Qusyairî., Al-Jâmi'al-Shahîh AlMusammâ Shahîh Muslim. Beirût: Dâr Al-Afâq Al-Jadîdah, Tt.

Al-Qardhawi, Y. A. (1993). Bagaimana Memahami Hadis Nabi Saw. Karisma, Bandung.

Ashur, I., \& 'Asyur, M. T. (2018). Maqasid Al-Syari'ah Al-Islamiyyah. Beirut: Dar Al-Salam.

Atmawati, M. V. (2016). Menyingkap Nilai-Nilai Wanita Shalihah Melalui Figur Ummu Salamah Dan Kontribusinya Dengan Pendidikan Akhlak. Stain Ponorogo.

Awalia, N., Triyono, A., \& Nur Latifah, U. S. (2016). Jilbab Dan Identitas Diri Muslimah Studi Kasus Pergeseran Identitas Diri Muslimah Di Komunitas Solo Hijabers Kota Surakarta. Universitas Muhammadiyah Surakarta.

Bayan, A. (2010). Shahih Bukhari Muslim. Bandung: Jabal.

Bin Sidik, M. A., \& Berahim, A. Z. (2013). Metodologi Al-Sakhawi Dalam Penulisan Kitab Al-Tuhfat Al-Lațîfah Fī Tarīkh Al-Madīnah Al-Syarīfah. Journal Of Al-Tamaddun, 8(1).

Hasan, B. (2019). Gender Dan Ketidak Adilan. Jurnal Signal, 7(1), 46-69.

Mernissi, F. (1997). Seks Dan Kekuasaan (Masyhur Abadi, Ed.). Surabaya: Alfikr.

Nurkholidah, N. (2016). Kritik Hadis Perspektif Gender (Studi Atas Pemikiran Fatima Mernissi). Holistik, 15(1).

Sugiyono. (2013). Metode Penelitian Pendidikan Pendekatan Kauntitatif, Kualitatif Dan R\&D. Bandung: Alfabeta.

Suhra, S. (2013). Kesetaraan Gender Dalam Perspektif Al-Qurâ€ $€^{\mathrm{Tm}}$ An Dan Implikasinya Terhadap Hukum Islam. Al-Ulum, 13(2), 373-394. 